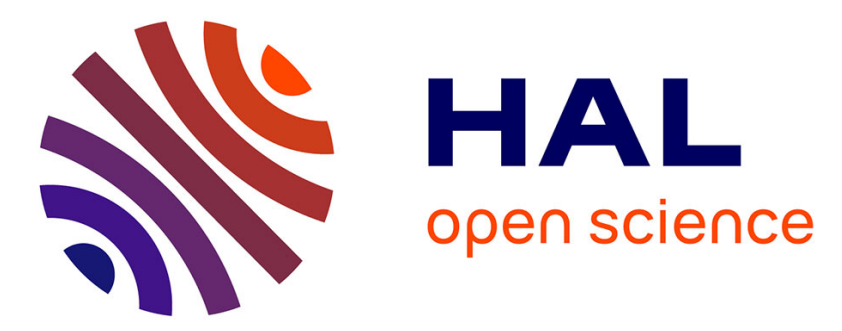

\title{
Length-weight relationship and seasonal effects of the Summer Monsoon on condition factor of Terapon jarbua (Forsskål, 1775) from the wider Gulf of Aden including Socotra Island
}

\author{
Edouard Lavergne, Uwe Zajonz, Lucie Sellin
}

\section{To cite this version:}

Edouard Lavergne, Uwe Zajonz, Lucie Sellin. Length-weight relationship and seasonal effects of the Summer Monsoon on condition factor of Terapon jarbua (Forsskål, 1775) from the wider Gulf of Aden including Socotra Island. Journal of Applied Ichthyology, 2012, 29, pp.274-277. 10.1111/j.14390426.2012.02018.x . hal-00778414

\author{
HAL Id: hal-00778414 \\ https://hal.univ-brest.fr/hal-00778414
}

Submitted on 20 Jan 2013

HAL is a multi-disciplinary open access archive for the deposit and dissemination of scientific research documents, whether they are published or not. The documents may come from teaching and research institutions in France or abroad, or from public or private research centers.
L'archive ouverte pluridisciplinaire HAL, est destinée au dépôt et à la diffusion de documents scientifiques de niveau recherche, publiés ou non, émanant des établissements d'enseignement et de recherche français ou étrangers, des laboratoires publics ou privés. 
Cite as: Lavergne, E., Zajonz, U. \& Sellin, L. (2013) Length-weight relationship and seasonal effects of the Summer Monsoon on condition factor of Terapon jarbua (Forsskål, 1775) from the wider Gulf of Aden including Socotra Island. Journal of Applied Ichthyology, 29 (1), 274-277. DOI: 10.1111/j.1439-0426.2012.02018.x

\title{
Length-weight relationship and seasonal effects of the Summer Monsoon on condition factor of Terapon jarbua (Forsskål, 1775) from the wider Gulf of Aden including Socotra Island
}

Edouard Lavergne ${ }^{1,2,3,4}$, Uwe Zajonz, 2,1 Lucie Sellin $^{3,4}$

Senckenberg Forschungsinstitut und Naturmuseum, Sektion Ichthyologie, Frankfurt am Main, Deutschland Biodiversität und Klima Forschungszentrum (BiK-F), Frankfurt am Main, Deutschland

Université de Bretagne Occidentale, UMR 6539, CNRS/IRD/UBO, Laboratoire des Sciences de l'Environnement Marin LEMAR, Institut Universitaire Européen de la Mer, Plouzané, France

Corresponding author: E. Lavergne, Tel +33298498627

Email address: edouard.lavergne@gmail.com

Address: LEMAR, Rue Dumont d'Urville, 29280 Plouzané, France

\begin{abstract}
The present study investigates the length-weight relationship and the condition factor of populations of the Indo-Pacific fish Terapon jarbua (Forsskål, 1775) collected in the wider Gulf of Aden, notably from Socotra Island and the Hadramout coast of Yemen. This region displays a monsoon climate, with wide seasonal variation affecting estuarine habitats. A total of 620 specimens collected in estuaries and at sea were measured and weighted during field surveys carried out in 2007 and 2008 during pre- and post- South-Western monsoon periods. The length-weight relationship of the studied populations of Terapon jarbua is determined as $\mathrm{W}=0.0288 \times \mathrm{SL}^{2.99}$, with $\mathrm{r}^{2}=0.96$ and is consistent with existing data on the species from other regions. Significant seasonal differences were found in Fulton's condition factor of Terapon jarbua.
\end{abstract}

Keywords: Terapon jarbua, length-weight relationship, condition factor, monsoon, Gulf of Aden, Socotra Island

\section{Introduction}

The grunter Terapon jarbua (Terapontidae, Perciformes) locally known as "Dirhar" in Yemen mainland and "Habraham" on Socotra Island, inhabits marine and brackish waters of the Indo-West Pacific (Klausewitz and Nielsen, 1965; Nielsen, 1974; Vari, 1978) and the Eastern Mediterranean (Golani and Appelbaum-Golani, 2010). Estimates on length-weight relationships (LWR) for this species have been reported from populations in Thailand (Yanagawa, 1994), Indonesia (Pauly et al., 1996), New Caledonia (Kulbicki et al. 2005; Letourneur et al., 1998), South Africa (Harrison, 2001) and China (Zhang et al., 2002). 
The climate of the studied region is characterized by the alternating monsoon seasons in the Northern Indian Ocean driven by the Inter-Tropical Convergence Zone (ITCZ). From October to February the weaker Winter or North-East Monsoon dominates with a rainy period starting in October and being strongest in November/December. From April/May to September the forceful Summer or South-West Monsoon blows strong hot winds that generate upwelling of cold nutrient-rich waters on both the North and South coasts of Socotra, and on the South coast of Yemen mainland (Fleitmann et al., 2004; Fratantoni et al., 2006; Klaus and Turner, 2004; Scholte and De Geest, 2010). The objective of the present study is to compare LWR of Terapon jarbua from the wider Gulf of Aden region with that from other regions and to assess seasonal effects of the Summer Monsoon on Fulton's condition factor K (Froese, 2006; Muchlisin et al., 2010; Pauly, 1984).

\section{Materials and methods}

\section{Sampling and measurements}

620 specimens of Terapon jarbua were sampled using a $30 \mathrm{~m}$ seine net (10 mm mesh size) at different locations in the wider Gulf of Aden region including Socotra Island and the Hadramout coast of Yemen from 2007 to 2008 during pre- and post- South-Western monsoon periods. The Standard Length (SL) of all observed specimens ranged from 4.7 to $27.9 \mathrm{~cm}$, with a mean value of $8.7 \mathrm{~cm}$. All specimens were measured to the nearest $0.1 \mathrm{~cm}$ and weighed (W) to the nearest gramme.

\section{Length-weight relationship}

The sex was not differentiated in this study. Although most of the samples were juveniles it is appreciated that sex may have affected the LWR. The LWR was determined by the equation $\mathrm{W}=a \times \mathrm{SL}^{b}$. Both parameters $a$ and $b$ were estimated by ordinary least squares regression through a logarithmic transformation of the data: $\log (\mathrm{W})=\log (a)+b \times \log (\mathrm{SL})$ where $\log (a)$ 
is the intercept and $b$ the slope of the regression line (Clark, 1928; Froese, 2006; Keys, 1928; Kulbicki et al., 2005). The hypothesis of isometric growth was tested by Student's $t$-test. To compare the estimates found in this study with those reported by other authors in different areas of the Indo-Pacific region (Table 1), Froese (2006) proposed to correct parameter $a$ by applying the following formula: $a^{\prime}=a \times 10^{b}$ (from data in $\mathrm{mm}$ and $\mathrm{g}$ to data in $\mathrm{cm}$ and $\mathrm{g}$ ).

\section{Fulton's condition factor}

The Fulton's condition factor was calculated for each individual fish according to the equation: $\mathrm{K}=100 \times \mathrm{W} \times \mathrm{SL}^{-3}$ (Froese, 2006; Muchlisin et al., 2010; Pauly, 1984), and since $b=2.99$ close to 3 , condition factor could be compared for different length (Froese, 2006). As the hypotheses of normality (Shapiro and Wilk, 1965) and homoscedasticity (Bartlett, 1937) were not met for all populations $(p<0.05)$, differences in $\mathrm{K}$ were investigated using KruskalWallis tests (Kruskal and Wallis, 1952). Due to time restrictions and site access denied by some local village authorities, seasonal comparison was only possible for Khor Dubena (Khor = estuary or coastal lagoon) and spatial comparison was only possible for the pre-monsoon periods. Additionally Nemenyi-Damico-Wolfe-Dunn post-hoc tests (Hollander and Wolfe, 1999) were performed to identify among which seasons and among which locations differences occur. All statistical analyses were performed using the function shapiro.test, bartlett.test and kruskal.test of the $\mathrm{R}$ package stats and the function oneway_test of the $\mathrm{R}$ package coin (Ihaka and Gentleman, 1996).

\section{Results and discussion}

\section{Length-weight relationship}

The LWR of Terapon jarbua is $\mathrm{W}=0.0288 \times \mathrm{SL}^{2.99}$, with $\mathrm{r}^{2}=0.96$ as represented in Fig. 1 . Descriptive statistics and estimated LWR parameters of T. jarbua from this study and from other studies are summarized in Table 1 . The value of the parameter $b$ in the present study was 
not significantly different from three $(\mathrm{t}=-0.314, p>0.05)$; therefore the hypothesis of isometric growth for T. jarbua in the wider Gulf of Aden was not rejected (Froese, 2006; Giacalone et al., 2010; Harrison, 2001). Different types of length measurements (Standard Length, Total Length and Fork Length) used by the different authors might have altered the estimation of parameter $a$ but not $b$ (Froese, 2006). In order, however, to compare the estimates found in this study with other authors' estimates, the $\log (a)$ was plotted against $b$ (Fig. 2) and proved to be consistent with existing data for Terapon jarbua.

\section{Fulton's condition factor}

The values for $\mathrm{K}$ ranged from 1.399 to 4.523 . At Khor Dubna, significant differences in $\mathrm{K}$ between pre- and post-monsoon samples in 2007 and $2008(p<0.01)$ were found with $\mathrm{K}$ mean values higher during the post-monsoon than the pre-monsoon periods. No difference was found between years (Fig. 3). Seasonal changes in body weight and in protein, lipid and water contents in fishes as been reported in several studies (Weatherley and Gill, 1987) and is usually driven by the food availability, the environmental conditions and the reproductive status of the fishes; this last parameter being not considered in the data mainly measured on juveniles. The high $\mathrm{K}$ values during the post- Summer Monsoon period are the direct consequences of the upwelling responsible of higher productivity and food availability. Indeed upwelling systems of cold nutrient-rich waters are formed, promoting high primary and secondary productivity (Klaus and Turner, 2004). Strong coastal wind and wave action establish connections between estuaries and the fertile ocean water masses which are otherwise often partly or fully isolated from each other. Thus, the high availability of nutrition, and the favorable environmental conditions during the South-West Monsoon (e.g.: lower water temperatures and salinity, higher oxygenation levels) allow fishes to increase in weight in a short period of time. By contrast the low K values during the pre- Summer Monsoon period 
can be explained by the degradation of environmental conditions (e.g.: higher water temperatures and salinity up to $39 \%$, lower oxygenation levels) and nutritional impoverishment in the estuaries.

The null hypothesis of no differences between fish condition factors during the same season at different locations could not be rejected for most locations. However, two locations Khor Dubena and Khor Bidholeh both located on Socotra Island were significantly different in K ( $p<0.01$ ) than all other locations (Fig. 4). The low K values of T. jarbua individuals at Khor Dubena can probably be explained (1) by the high fish diversity (27 species) inducing a high inter-specific competition for food and (2) by the high abundance of large predators such as the jack Caranx heberi (Bennett, 1830), the snappers Lutjanus argentimaculatus (Forsskål, 1775) and Lutjanus fulviflamma (Forsskål, 1775) and the emperor Lethrinus nebulosus (Forsskål, 1775). Moreover this estuary is often closed from the sea for several months with only occasional water exchange with the ocean thus further reducing food availability for $T$. jarbua during these periods. The high $\mathrm{K}$ values at Khor Bidholeh could be related to the presence of a small fish landing site. Indeed, fish wastes have been observed as being directly discarded into the estuary and could represent a non negligible source of food for T. jarbua which constitute the dominant species of this estuary.

Terapon jarbua is a temporal resident of coastal estuaries in the study area and occasionally targeted in the local subsistence fisheries. More generally, over the Indo-West Pacific, juveniles of $T$. jarbua are abundant in brackish waters as in the mangroves of Madagascar (Laroche et al., 1997), where this species represent $16 \%$ of the catch (i.e.: the second rank after the Gerreidae). The present study provides basic information on the LWR and seasonal condition of T. jarbua populations in the wider Gulf of Aden region in support of sustainable management of the species and especially of the estuaries of the coasts of Socotra Island and the Hadramout, Yemen. 


\section{Acknowledgments}

The present study was mainly funded by the Total Foundation, Paris. It was partially conducted at the Socotra Field Research Station of the Biodiversity and Climate Research Centre (BiK-F), Frankfurt a.M., based on financial support of the research-funding programme "LOEWE - Landes-Offensive zur Entwicklung Wissenschaftlich-ökonomischer Exzellenz" of Hesse's Ministry of Higher Education, Research, and the Arts. Additional mobility funds were provided by scholarships from the GRADE - Goethe Graduate Academy of the Goethe University Frankfurt a.M. and the International Doctoral College of the European University of Brittany (UEB). His Excellency the former Minister of Water and Environment of the Republic of Yemen, Eng. Abdul-Rahman F. Al-Eryani, and His Excellency the Chairman of the Environment Protection Authority, Eng. Mahmoud Shidiwa, are cordially acknowledged for their continued support and for granting research and sample export permits. The Socotra Conservation and Development Program (SCDP-UNDP) is thanked for providing indispensable support during the field work. We would like to thank the People of Socotra and in particular the members of the coastal communities which kindly facilitated field work and provided access to the areas in their care. We wish to express our gratitude to Fouad Naseeb and Motea Sheikh Aideed for their efficient assistance in the field, to Dr. El-Mashjary and Dr. Ali of the Hadramout University for granting the authors access to the University wet laboratory, to Louis Quiniou and Jacques Baron for their advice concerning the statistical treatment of the data and to Friedhelm Krupp and Jean Laroche for their support to the $\mathrm{PhD}$ project of the first author. 


\section{References}

Bartlett, M.S., 1937: Properties of sufficiency and statistical tests. Proceedings of the Royal Society of London Series A - Matematical and Physical Sciences. 160, 268-282.

Bennett, J.W., 1828-1830: A selection from the most remarkable and interesting fishes found on the coast of Ceylon, London.

Clark, F.N., 1928: The weight-length relationship of the California sardine (Sardina caerulea) at San Pedro. Division of Fish and Game, Fish Bull. 12, 59.

Fleitmann, D.; Matter, A.; Burns, S.J.; Al-Subbary, A.; Al-Aowah, M.A., 2004: Geology and Quaternary climate history of Socotra. Fauna of Arabia. 20, 27-43.

Forsskål, P., 1775: Descriptiones animalium avium, amphibiorum, piscium, insectorum, vermium; quae in itinere orientali observavit. Copenhagen, Mölleri pp. 164.

Fratantoni, D.M.; Bower, A.S.; Johns, W.E. and Peters, H. 2006: Somali Current rings in the eastern Gulf of Aden. Journal of Geophysical Research. 111, 1-19.

DOI: $10.1029 / 2005 J C 003338$.

Froese, R., 2006: Cube law, condition factor and weight-length relationships: history, metaanalysis and recommendations. Journal of Applied Ichthyology. 22(4), 241-253.

DOI: 10.1111/j.1439-0426.2006.00805.x.

Froese, R.; Pauly, D., 2011: FishBase. World Wide Web electronic publication www.fishbase.org, version (11/2011).

Giacalone, V.M.; D’Anna, G.; Badalamenti, F.; Pipitone, C., 2010: Weight-length relationships and condition factor trends for thirty-eight fish species in trawled and untrawled areas off the coast of Northern Sicily (central Mediterranean Sea). Journal of Applied Ichthyology. 26(6), 954-957. DOI: 10.1111/j.1439-0426.2010.01491.x.

Golani, D.; Appelbaum-Golani, B., 2010: First record of the Indo-Pacific fish the Jarbua terapon (Terapon jarbua) (Osteichthyes: Terapontidae) in the Mediterranean with remarks on the wide geographical distribution of this species. Scientia Marina. 74(4), 717-720. 
DOI: $10.3989 /$ scimar.2010.74n4717.

Harrison, T.D., 2001: Length-weight relationships of fishes from South African estuaries. Journal of Applied Ichthyology. 17(1), 46-48.

Hollander, M.; Wolfe, D.A., 1999: Nonparametric statistical methods. John Wiley \& Sons, New York; Chichester.

Ihaka, R.; Gentleman, R., 1996: R: A Language for Data Analysis and Graphics. Journal of Computational and Graphical Statistics. 5(3), 299-314.

Keys, A.B., 1928: The Weight-Length Relation in Fishes. Proceedings of the National Academy of Sciences. 14(12), 922-925.

Klaus, R.; Turner, J., 2004: The marine biotopes of the Socotra Island Group. Fauna of Arabia. 20, 45-115.

Klausewitz, W.; Nielsen, J.G., 1965: On Forsskål's collection in the Zoological Museum of Copenhagen. Spolia zoolgical museum Hauniensis, Copenhagen, 1-29.

Kruskal, W.H.; Wallis, W.A., 1952: Use of ranks in one-criterion variance analysis. Journal of the American Statistical Association. 47(260), 583-621.

Kulbiki, M.; Guillemot, N.; Amand, M., 2005: A general approach to length-weight relationships for New Caledonian lagoon fishes. Cybium. 29(3), 235-252.

Laroche, J.; Baran, E.; Rasoanandrasana, B., 1997: Temporal patterns in a fish assemblage of a semiarid mangrove zone in Madagascar. Journal of Fish Biology. 51(1), 3-20.

DOI: 10.1111/j.1095-8649.1997.tb02509.x.

Letourneur, Y.; Kulbiki, M.; Labrosse, P., 1998: Length-weight relationships of fish from coral reefs and lagoons of New Caledonia, southwestern Pacific Ocean: an update. Naga ICLARM Q. 21(4), 39-46.

Muchlisin, Z.A.; Musman, M.; Siti Azizah, M.N., 2010: Length-weight relationships and condition factors of two threatened fishes, Rasbora tawarensis and Poropuntius tawarensis, 
endemic to Lake Laut Tawar, Aceh Province, Indonesia. Journal of Applied Ichthyology. 26(6), 949-953. DOI: 10.1111/j.1439-0426.2010.01524.x.

Nielsen, J.G., 1974: Fish types in the Zoological Museum of Copenhagen. Zoological Museum, University of Copenhagen, Denmark, 115.

Pauly, D., 1984: Fish population dynamics in tropical waters. International Center for Living Aquatic Resources Management, Manila, Philippines pp. xvii, 325.

Pauly, D.; Cabanban, A.; Torres, F.S.B., Jr., 1996: Fishery biology of 40 trawl-caught teleosts of western Indonesia. Pages 135-216, in: D. Pauly and P. Martosubroto (eds.): Baseline studies of biodiversity: the fish resource of western Indonesia. Martosubroto, ICLARM.

Scholte, P.; de Geest, P., 2010: The climate of Socotra Island (Yemen): A first-time assessment of the timing of the monsoon wind reversal and its influence on precipitation and vegetation patterns. Journal of Arid Environments. 74, 1507-1515.

DOI: 10.1016/j.jaridenv.2010.05.017.

Shapiro, S.S.; Wilk, M.B., 1965: An analysis of variance test for normality (complete samples). Boimetrika. 52, 591.

Vari, R.P., 1978: The terapon perches (Percoidei, Teraponidae): a cladistic analysis and taxonomic revision. Bulletin of the American Museum of Natural History. 159(5), 175340.

Weatherley, A.H.; Gill, H.S., 1987: The biology of fish growth. Acad. Pr., London pp. 443.

Yanagawa, H., 1994: Length-weight relationship of Gulf of Thailand fishes. Naga ICLARM Q. 17(4), 48-52.

Zhang, J., Song, B., Chen, G., 2002: Study on the age and growth of Therapon jarbua. Marine Science. 26(7), 66-70. 
Table 1: Descriptive statistics and estimated parameters of length-weight relationships for Terapon jarbua

\begin{tabular}{|c|c|c|c|c|c|c|c|c|c|}
\hline & & \multicolumn{3}{|c|}{ Length (cm) } & \multicolumn{5}{|c|}{ LWR Parameters } \\
\hline & $n$ & Min & Max & & $A$ & $a \mathrm{Cl} 95 \%$ & $b$ & $b \mathrm{Cl} 95 \%$ & $\mathbf{r}^{2}$ \\
\hline Present study & 620 & 4.7 & 27.9 & SL & 0.0288 & 0.0262-0.0318 & 2.99 & 2.95-3.04 & 0.96 \\
\hline Kulbicki et al. $2005 *$ & 87 & 2.0 & 28.5 & FL & 0.0132 & - & 3.13 & - & 0.98 \\
\hline Zhang et al. $2002 *$ & - & - & - & - & 0.0389 & - & 2.87 & - & - \\
\hline Harrison $2001 * *$ & 70 & 1.0 & 14.8 & SL & 0.0340 & - & 2.94 & - & 0.99 \\
\hline Letourneur et al. $1998 *$ & 97 & 2.0 & 28.5 & FL & 0.0154 & - & 3.08 & - & 0.98 \\
\hline Pauly et al. $1996^{*}$ & - & 8.0 & 19.0 & FL & 0.0748 & - & 2.52 & - & 0.98 \\
\hline Yanagawa $1994 *$ & 6 & 9.6 & 26.8 & $\mathrm{TL}$ & 0.0222 & - & 2.88 & - & 0.99 \\
\hline
\end{tabular}

n, sample size; Min, minimum; Max, maximum; FL, Fork Length; SL, Standard Length; TL, Total Length

* Data collected from FishBase (Froese and Pauly, 2011)

** Original length was in $\mathrm{mm}$ and weight in $\mathrm{g}$, parameter $a$ was corrected using the following equation: $a^{\prime}=a \times 10^{b}$ (Froese, 2006) 

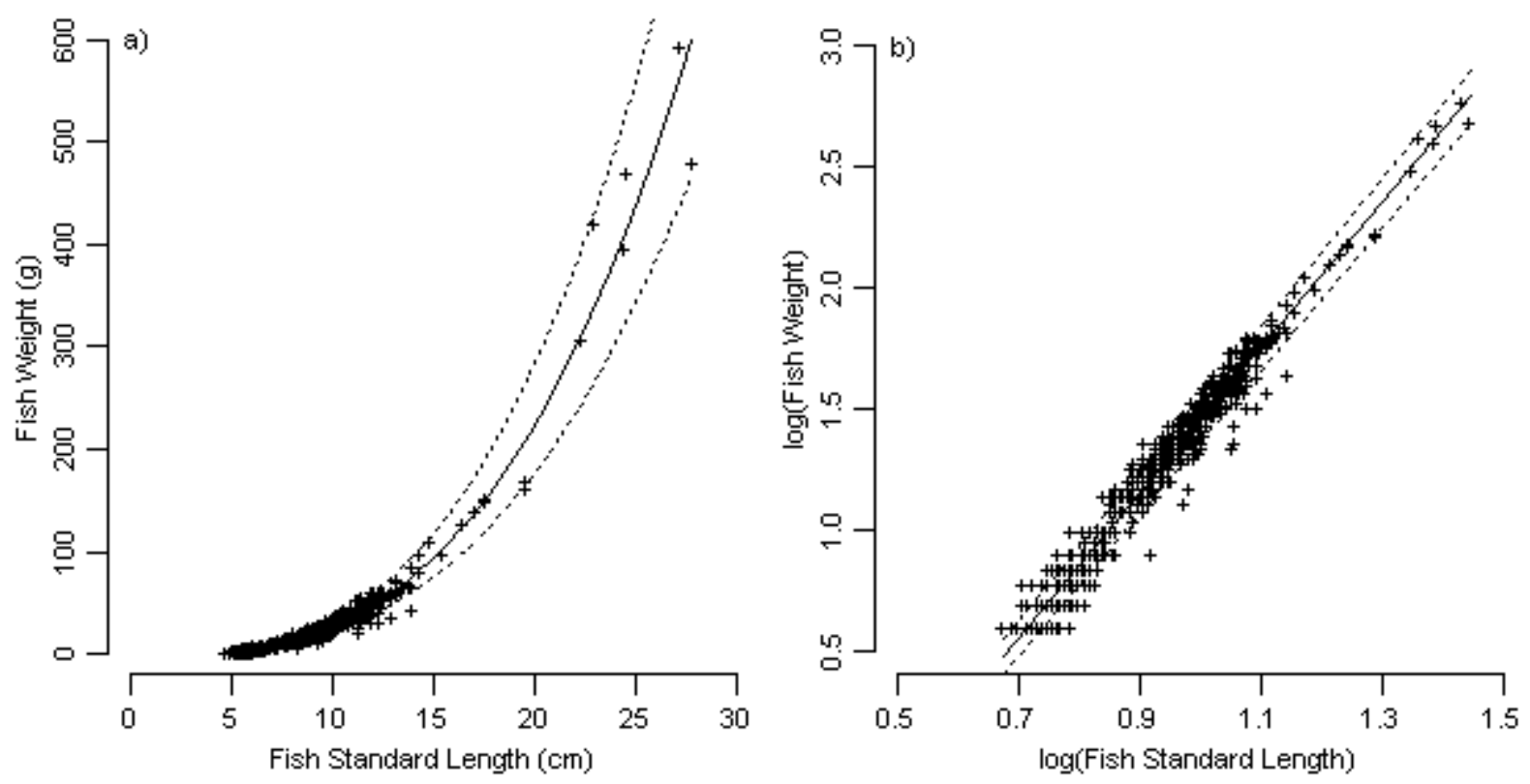

Figure 1: Length-weight relationship of Terapon jarbua from the wider Gulf of Aden

a) Regression of Fish Standard Length $v s$. Fish Weight, the plain curve represents the LWR regression curve $\mathrm{W}=0.0288 \times \mathrm{SL}^{2.99}, \mathrm{r}^{2}=0.96$ and the dotted curves represent the upper and lower $95 \%$ confidence limits of the LWR Regression curve. b) Linear regression of the log transformed data presented in a). 


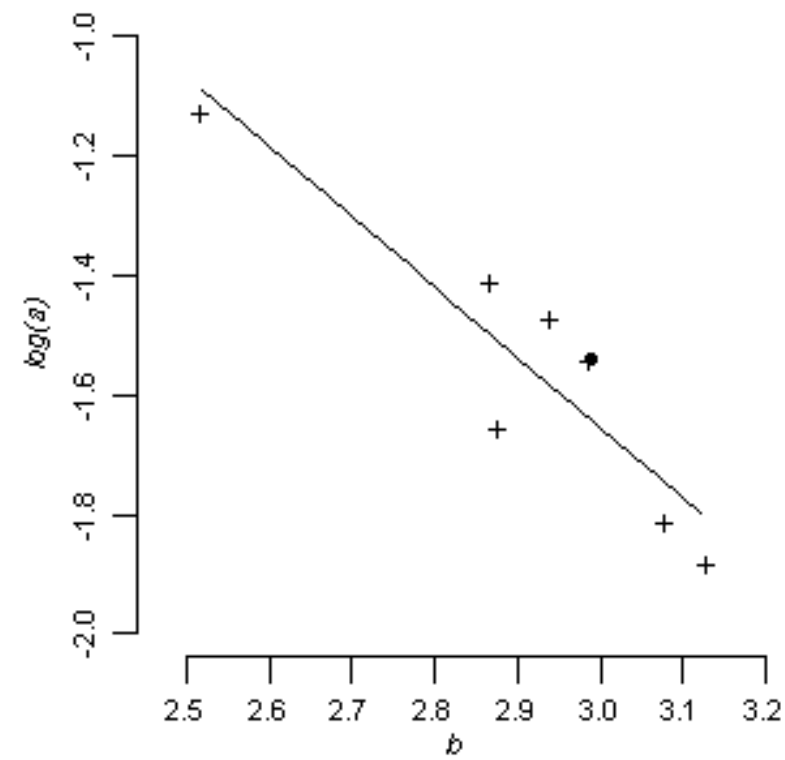

Figure 2: Test plot of $\log (a)$ against $b$ for seven LWRs of Terapon jarbua

The black dot identifies the present study parameters. The crosses represent the parameters of the six other studies (Table 1). The plain line represents the regression line, $r^{2}=0.84$. The extreme point on the left might be seen as an outlier, possibly because it includes a narrow range of juveniles 


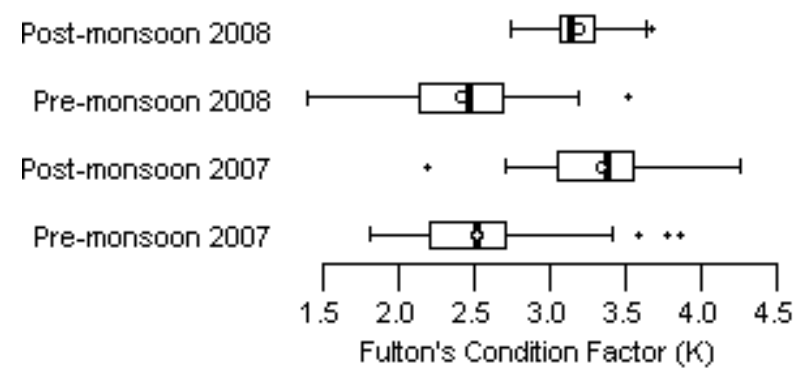

Figure 3: Box plot of condition factor $K$ for Khor Dubena during pre- and post- Summer Monsoon periods of 2007 and 2008

The open circles represent the mean condition factor, the vertical dark bars represent the median condition factor, boxes encompass $50 \%$ of the data, whiskers encompass $95 \%$ and small crosses represent outliers. Only differences between seasons are significant $(p<0.01)$. 


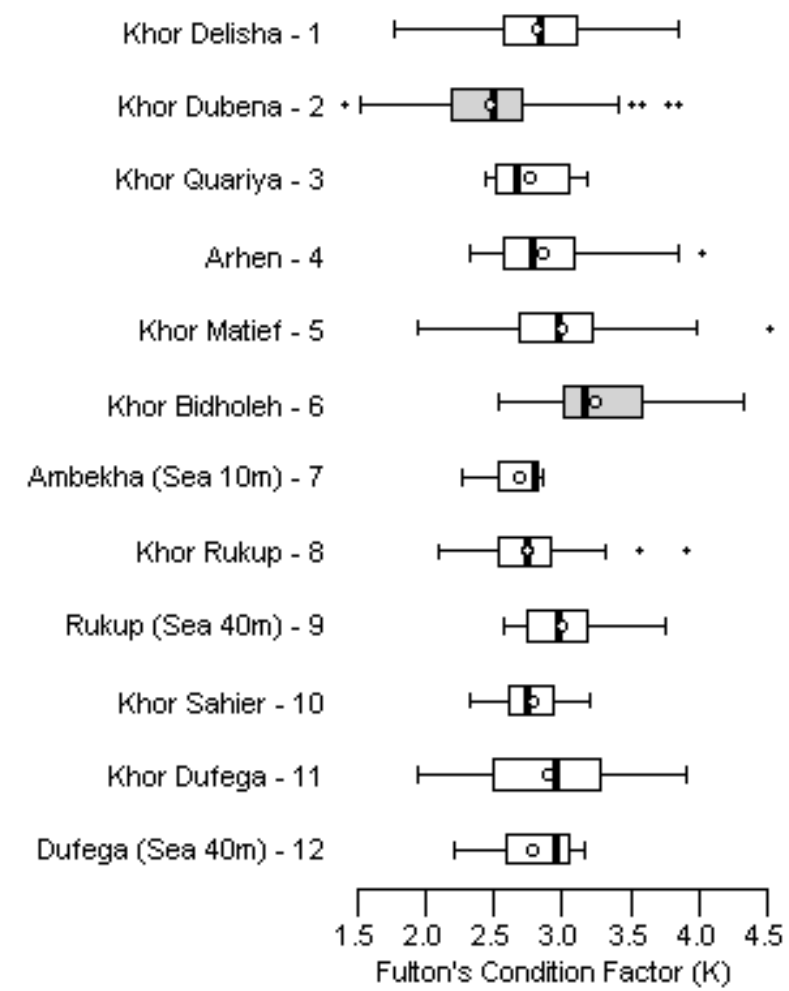

Figure 4: Box plot of condition factor $K$ per locations during pre- Summer Monsoon periods

The open circles represent the mean condition factor, the vertical dark bars represent the median condition factor, boxes encompass $50 \%$ of the data, whiskers encompass $95 \%$ and small crosses represent outliers. The light grey boxes represent the locations that are significantly different $(p<0.01)$ from all other locations. 